Article

\title{
Lusophone Entrepreneurship: Analysis of Entrepreneurial Behavioural Characteristics in Brazilian and Portuguese Universities
}

\author{
Débora Regina Schneider Locatelli ${ }^{1}$, Paulo Jorge Reis Mourão ${ }^{2}$ D and Rui Silva $^{3, * \mathbb{D}}$ \\ 1 Department of Administration, Federal University of Fronteira Sul, Chapecó, SC 89801-501, Brazil; \\ debora.locatelli@uffs.edu.br \\ 2 Department of Economics \& NIPE, University of Minho, 4710-057 Braga, Portugal; paulom@eeg.uminho.pt \\ 3 University of Trás-os-Montes e Alto Douro-CETRAD, 5001-801 Vila Real, Portugal \\ * Correspondence: ruisilva@utad.pt
}

check for updates

Citation: Schneider Locatelli, D.R.; Mourão, P.J.R.; Silva, R. Lusophone Entrepreneurship: Analysis of

Entrepreneurial Behavioural

Characteristics in Brazilian and Portuguese Universities.

Sustainability 2021, 13, 4568.

https://doi.org/10.3390/su13084568

Academic Editor: José

Carlos Sánchez-García

Received: 13 March 2021

Accepted: 6 April 2021

Published: 20 April 2021

Publisher's Note: MDPI stays neutral with regard to jurisdictional claims in published maps and institutional affiliations.

Copyright: (C) 2021 by the authors. Licensee MDPI, Basel, Switzerland. This article is an open access article distributed under the terms and conditions of the Creative Commons Attribution (CC BY) license (https:// creativecommons.org/licenses/by/ $4.0 /)$

\begin{abstract}
This study analyzes the entrepreneurial characteristics of students from public universities. The objective was to evaluate the presence of the characteristics of entrepreneurship pointed out by McClelland through a comparative analysis between two countries and through an analysis using structural models. Data collection was performed with the questionnaire prepared by David McClelland that assesses entrepreneurial behavioural characteristics through 55 preliminary questions. Data were collected from 329 respondents at universities in Brazil and Portugal during 2019. A quantitative analysis was performed using AMOS 26 software, and structural equation models were tested for the three groups under analysis. The analysis resulted in the validation of three measurement models (Portuguese (PT) and Brazilian (BR), PT, and BR), and it was observed that all dimensions were relevant and statistically significant in the set of PT and BR simultaneously and in the BR group. For the PT group, only the dimension "taking calculated risks", corresponding to H2, did not have statistical validity.
\end{abstract}

Keywords: entrepreneur; academics; entrepreneurial behavioural characteristics

JEL Classification: A22—undergraduate; L260—entrepreneurship

\section{Introduction}

The authors recognize the stimuli provided by three anonymous reviewers of Sustainability. The remaining limitations are authors' exclusive ones.

Entrepreneurship and its protagonist, the entrepreneur, has been a recurring subject in academic research, as pointed out by Filion (1999) [1], who cited the growing number of researchers devoting themselves to the field of entrepreneurship, because of both the growth of new enterprises and the increasing participation in the gross domestic product (GDP) of micro-, small-, and medium-sized enterprises in different countries year by year. Another interesting factor of this theme is that entrepreneurship permeates various areas of knowledge, such as economics, administration, and psychology [2].

Although there has been a long period of maturity since Schumpeter, who is seen as creating one of the cornerstones of the concept, further research in the area of entrepreneurship is needed in order to broaden the current knowledge, which has led to a narrowing of knowledge generated in the area of entrepreneurship [3].

Entrepreneurship has been analyzed as being likely to be developed at any stage of people's lives. However, studies such as those by Ching and Kitahara (2017, p. 291) [4] show particular attention to the entrepreneurship of college students. Their results [4] demonstrated that young people are "[ ... ] highly inclined towards entrepreneurship and in need of achievement". Other studies detailed in this paper highlight the relevance of an analysis of the propensity for entrepreneurial attitudes in samples of young 
and university populations, not only as a promoter of the analysis of commitments to the ability to develop innovative solutions to emerging problems-the core concept of entrepreneurship - but also anticipating more significant challenges in planning and public policy. A number of studies published in 2019 have researched entrepreneurship in the academic environment [5-15]. These studies have increased academic interest in in-depth research of entrepreneurial behavioural characteristics (EBCs) in college students. As we detail in Section 3, comparative analyses involving samples from differentiated universities and other institutions of higher learning in various countries have also been encouraged, not only to gauge the common characteristics of this range of entrepreneurs, but also to leverage the distinctive dimensions. For this purpose, Brazilian and Portuguese university students were surveyed. In addition to the fact that the authors are from these countries, this sample selection is based on Filion's (1999) [1] point that entrepreneurial behaviour is a phenomenon with strong national and regional influence, based on the cultural needs and habits of a country.

Furthermore, Fontela, Guzmán, Pérez, and Santos (2006) [16] stated that personal entrepreneurial qualities are influenced by several environmental factors, including personal factors, represented by family, education, and professional experiences, and sociocultural factors, which are more global and present the entrepreneur with information and opportunities, and contribute to the evolution of attitudes and values. Researchers have often considered the university environment as a stimulating setting for the development of entrepreneurship. This was corroborated by Guerra and Grazziotin (2010) [17], who wrote that higher education institutions help promote an entrepreneurial culture.

One of the original points of this study is that it focuses on the entrepreneurial behavioural characteristics (EBCs) studied by David McClelland, comparing the results between Brazilian and Portuguese university students. Thus, we can clearly define our research question as follows: How are EBCs developed by university students, considering samples from Brazilian and Portuguese universities? The associated objective thus analyzes how EBCs develop in students, highlighting the most relevant dimensions and establishing a comparative analysis.

Therefore, we will focus on lusophone entrepreneurship. For lusophone entrepreneurship, we intend to identify the entrepreneurship activity across lusophone countries, although in this paper we only focus on Brazilian and Portuguese cases.

The article is divided into five sections. The second section presents the theoretical framework of the entrepreneur and the entrepreneurial behavioural characteristics. The third presents the methodological procedures used for the elaboration of this study. In the fourth section, the research findings are presented and discussed. Finally, the fifth section offers the conclusions of the study.

\section{Theoretical Review}

\subsection{Entrepreneur and Entrepreneurship}

The entrepreneur is one who creates something new and valuable, thereby taking financial and social risks, but also expecting to reap economic and social rewards [18]. The entrepreneur has a particular way of perceiving what is happening in a specific sector [19]. He or she, thus, accumulates knowledge, different attitudes, behaviours, ways of perceiving the world and himself or herself; develops activities that involve risk; and has the personal attributes that lead to the abilities to innovate, persevere, and live with uncertainty [20]. Moreover, entrepreneurship is a distinct characteristic of every individual who can learn to undertake lifelong learning, because it is a behaviour rather than a personality trait [21].

Pradhan and Nath (2012) [22] distinguished two dimensions that may characterize the entrepreneur, namely: the need for accomplishment, which had previously been studied by McClelland (1965) [23], and the locus of control, which is the perception of having control over life events. For McClelland (1972) [24], the entrepreneur's desire to accomplish something expresses a desire to overcome and differentiate oneself, and this often results 
in economic activity. The behavioural insight that will be used in this study follows the work of David McClelland. For him, the entrepreneur often develops the EBC [25].

Although the entrepreneur is often seen as the "wandering knight" of capitalism, according to Schumpeter (1949) [3], entrepreneurship has emerged in the literature as a theme that increasingly involves studies of the entrepreneur profile and his/her endogenous characteristics, as well as reviews of the entrepreneurship and innovative solutions environment, as detailed below.

\subsection{Entrepreneurial Behavioural Characteristics}

The concept of entrepreneurial behavioural characteristics (EBCs) was developed by David McClelland (1961) [26]. They are organized as three major categories into which the 10 major characteristics are distributed, as shown in Table 1.

Table 1. Categories, characteristics, and attributes.

$\begin{array}{lll}\text { Categories } & \text { Characteristics } & \text { Attributes }\end{array}$

Identify and act on new opportunities;

Search for opportunity and initiative this action can be done before being requested or forced to by the circumstances.

Realization:

Commitment to doing good work with creativity and intuition in order to achieve your goals and objectives in the best possible way; showing persistence, even in difficulties; assessing risks; and taking a balanced position.
Taking calculated risks

Demand for quality and efficiency

Deliberately assessing and calculating risks and taking measures to reduce risks or control results.

Find ways to do things better, faster, or more effectively, thus seeking to carry out your actions in a way that meets or exceeds expected standards of excellence.

Persistence Acting repeatedly to meet a challenge or overcome an obstacle.

Make a personal sacrifice or spend more effort to carry out an activity; take personal responsibility for the performance necessary to achieve goals and objectives.

Dedicate yourself personally to obtaining the information necessary for your activity.

Planning:

Search of data
The characteristics of this category support realization, as to perform a better risk assessment there is a need to search for information, planning, and monitoring. That is, to make you think before taking any action.

Planning and systematic monitoring

Define short- and long-term goals that are clear and specific and, if necessary, revise.

Plan by dividing large tasks into subtasks; constantly reviewing the plans, taking into account the results obtained and changing circumstances, and keeping records and using them to make decisions.

Using deliberate strategies to influence or

\section{Power:}

Linked to personal needs, that is, to be able to carry out actions as you wish and, if necessary, to get employees and partnerships. persuade others, using key people as agents to achieve goals.

Persuasion

Seeking autonomy in relation to the norms and controls of others, maintaining your point of view even in the face of opposition or initially discouraging results, and also expressing confidence in your own ability to complete a difficult task or face a challenge. 
The behavioural approach originated in the 1950s with McClelland's studies, and isolated the entrepreneur's psychological and cultural factors through quantitative methods [28]. With his studies on the theory of psychological motivation, McClelland (1961) [26] contributed to the understanding of entrepreneurship. EBCs contribute to the development of the entrepreneur as a dynamic social actor [29], even if the person was not born with such characteristics [30].

According to the literature review, the following research hypotheses are defined:

Hypothesis 1 (H1). Search for opportunity (SOO) has a positive effect on entrepreneurial behavioural characteristics (EBCS).

Hypothesis 2 (H2). Taking calculated risks (TCR) has a positive effect on entrepreneurial behavioural characteristics (EBCs).

Hypothesis 3 (H3). Requirement of quality (EOQ) has a positive effect on entrepreneurial behavioural characteristics (EBCs).

Hypothesis 4 (H4). Persistence (PER) has a positive effect on entrepreneurial behavioural characteristics (EBCs).

Hypothesis $\mathbf{5}$ (H5). Commitment (COM) has a positive effect on entrepreneurial behavioural characteristics (EBCs).

Hypothesis 6 (H6). Search for data (SFD) has a positive effect on entrepreneurial behavioural characteristics (EBCs).

Hypothesis 7 (H7). Goal definition (GOD) has a positive effect on entrepreneurial behavioural characteristics (EBCs).

Hypothesis 8 (H8). Planning (PLA) has a positive effect on entrepreneurial behavioural characteristics (EBCs).

Hypothesis 9 (H9). Persuasion (PSU) has a positive effect on entrepreneurial behavioural characteristics (EBCs).

Hypothesis 10 (H10). Independence (IND) has a positive effect on entrepreneurial behavioural characteristics (EBCS).

These hypotheses will make it possible to define the research model presented in Figure 1.

Figure 1 follows the original proposal by McClelland (1961) [26]. According to the author, the 10 dimensions analyzed constitute a single entrepreneurial factor, which can be tested through procedures associated with exploratory factor analysis or confirmatory factor analysis. Unlike other studies, such as that by Daud, Abdullah, and Abu Hassan (2019) [31], which found two or more factors by synthesizing several variables observed in entrepreneurial individuals, McClelland's (1961) [26] original proposal, by suggesting the unity of factors, claimed that there is a certain homogeneity in the entrepreneurial profile, and that all dimensions under observation do not exhibit enough variability to constitute a larger number of factors. On the issue of factor uniqueness in factor analysis, relevant empirical works are those of Snedecor and Cochran (1989) [32]. 


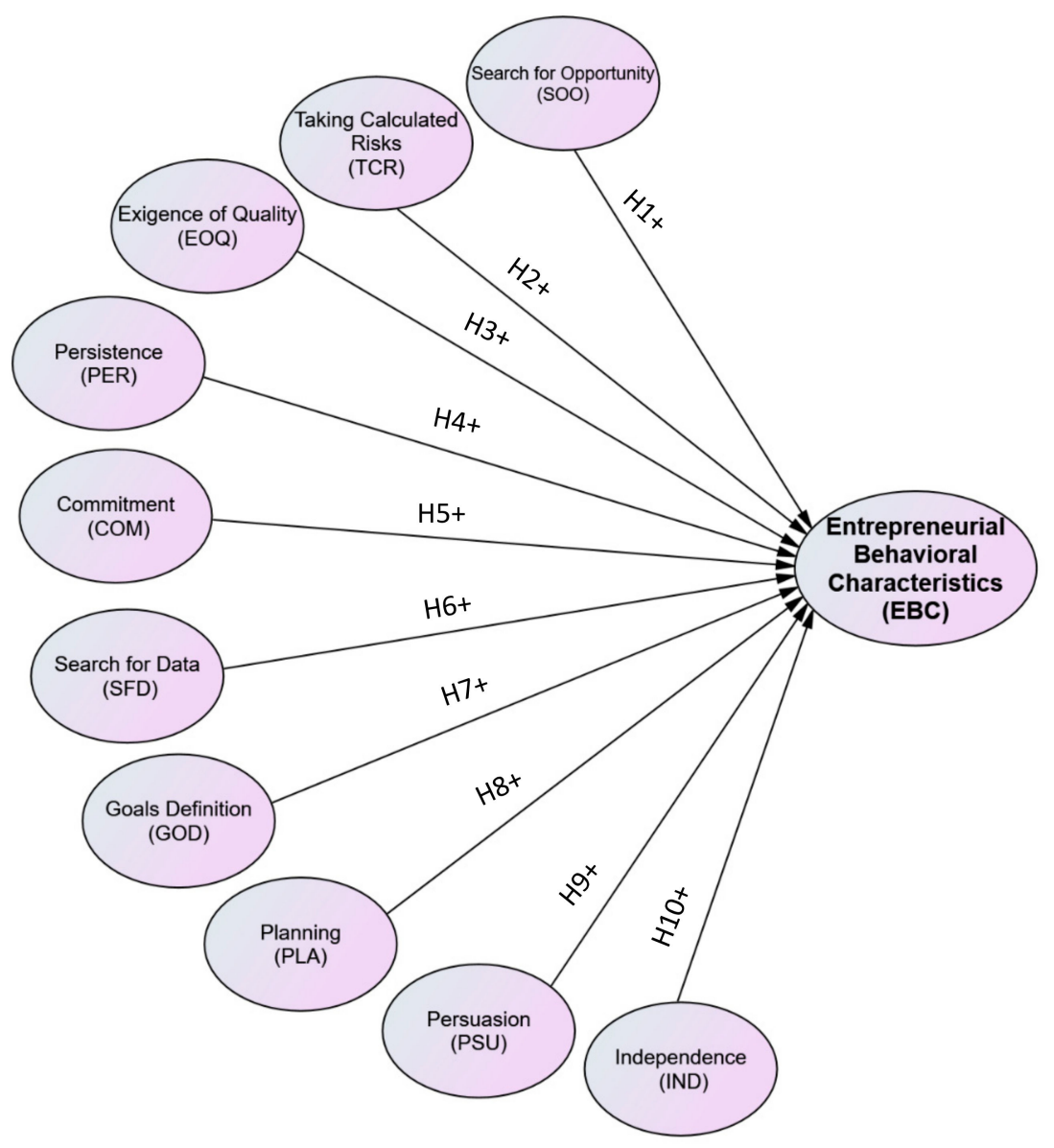

Figure 1. Research model.

\subsection{Entrepreneurship of University Students}

The issue of entrepreneurship in universities-most often triggered by professors and students-has ignited an interesting debate, as elucidated by authors with findings similar to those of Daud et al. (2019) [31] or Ajzen (1991) [33]. There is ample evidence that proves the weight of entrepreneurship seen in academia as an important source of entrepreneurship that the economy will welcome in the near future. College students will soon be in the job market, and will be engines of entrepreneurship in general. In addition, entrepreneurship does not appear only in the constitution of new companies, but it can present itself in already established companies (corporate entrepreneurship), in the collaborators/employees of public and private institutions (intrapreneurship), and in other for-profit institutions (social entrepreneurship, cultural, sports, academic, etc.). Thus, the study of entrepreneurship in the university environment reflects entrepreneurship actions in general [34].

The concept was developed as a unique opportunity to generate innovative solutions that transform market structures dominated by competitive differentiation factors or quasimonopolies [21]. Other authors such as Dvorski et al. (2019) [7] reported that university entrepreneurship is likely to be more closely aligned to the original entrepreneurship ideals than other forms of entrepreneurship (such as those based on complex funding figures), because university students generally do not have the distinguishing characteristics of other innovative agents, thereby allowing them to compete and take risks with more exposure to success or failure.

Authors including Kurniawan, Yudoko, Basri, and Umbara (2019) [35] reported that entrepreneurship among college students represents an interesting source of future economic growth and an unavoidable engine of socioeconomic development. Even the list of high 
number of endeavours is correlated with a higher future birth rate in the entrepreneurial undergraduate development economy.

However, as Bizarria et al. (2019) [9] reported, the success rate and even the application of the diversity of experiences in the context of university entrepreneurship are optimized only with a combination of specific factors. First, the initiative perspective focused on the action of the university entrepreneur should be addressed in order for it to survive. Second, the importance of short-term returns must be acknowledged; that is, social recognition, positive cash flow, profitable opportunities, and innovation or entrepreneurship awards cannot be ruled out. Third, university entrepreneurship is not a generalization of instruments, processes, resources, or challenges. Instead, it thrives on the variety of possibilities in the very diversity of entrepreneurship, the developing areas, and the resources themselves (human, material, financial, and organizational). Daud et al. (2019) [31] explained how university entrepreneurship in the field of engineering cannot follow the dominant lines of university entrepreneurship in management or administration, just as university entrepreneurship in itself must have development paths that are differentiated from finance.

In this section, we address the criticisms of Sá and Holt (2019) [36], among others. In this set of criticisms, university entrepreneurship is seen, above all, as a "soft-skills academy" rather than a rehearsal for entrepreneurial or industrial innovation behaviours. Given the unique characteristics of undergraduates, university entrepreneurship in this context is generally perceived as lacking the experience that older and more mature entrepreneurs possess. Authors such as Sá and Holt (2019) [36] stress the importance of university entrepreneurship as a necessary model for the sustained practice of entrepreneurship, but they generally do not place high expectations on the scope of its socioeconomic value.

\subsection{Comparative Entrepreneurship and an Analysis of EBCs in Higher-Education Students from} Brazil and Portugal

Differences in entrepreneurial economies have already led to detailed studies, such as those of McClelland (1972) [24]. Over the years, the dynamics themselves have developed differently from country to country, as noted by Felix, Aparicio, and Urbano (2020) [37], who mention several indicators.

Comparisons between academies or between countries regarding academic differentiation in terms of entrepreneurship indicators are scarcer. The studies by Brancher et al. (2012) [29] represent some of the exceptions in the literature. We consider this to be a gap in the literature that should be addressed. We offer three main reasons to justify this study. First, as Brancher et al. (2012) [29] pointed out, what happens in the academic environment in terms of entrepreneurship has significant consequences on the entrepreneurship, innovation, and management skills of organizations in the immediate future. Therefore, understanding comparative entrepreneurship is an essential step for effectively designing public policies in the sector. Second, the ability to perceive the sustainability of numbers in relation to entrepreneurial initiatives and agents assists in understanding each academy or university system as a generator of entrepreneurship. Third, as Hahn et al. (2019) [8] pointed out, the comparability between university hubs is methodologically more correct than between national economic systems in the field of entrepreneurship.

However, if we emphasize the comparative needs of academies in the field of entrepreneurship, we also emphasize the relevance of bringing this exercise to Brazilian and Portuguese academies. There are several reasons for this at the present time.

First, the universe of Brazilian and Portuguese academies is the lusophone, with an intensification of flows (teachers, students, co-authored articles, patents, etc.) in the last decade. Clearly, the scale of the initiatives and the diversity of the university education profile in Brazil is much broader than in Portugal, based on the formative network and complexity of Brazilian figures (such as federal, state, municipal, and private universities) compared with Portuguese (concentrated in public and private universities), in addition to technical or polytechnic institutes on both sides of the Atlantic. Other elements also sharply differentiate and motivate a more detailed analysis. 
The generation dynamics of start-ups and their associated development, a sector associated with university entrepreneurship as pointed out by Boava (2006) [2], are also significantly distinct between Brazil and Portugal.

In Brazil in 2019, a total of 53.4 million Brazilians were estimated to be in charge of some entrepreneurial activity, involved in the creation of a new enterprise, consolidating a new business, or making efforts to maintain an already established enterprise. With regard to initial entrepreneurship, which is considered to be projects younger than 42 months (3.5 years), the country reached 23.3\% [34]. The study also points out that Brazil resumed its growth in initial entrepreneurship after a fall registered between 2016 and 2018.

As for the profile of Brazilian entrepreneurs, it appears that in the initial entrepreneurs, there is minimal difference between women and men-the most active are aged between 25 and 44 years old and have completed higher education. In established entrepreneurs, with enterprises over 42 months old, men are the majority, aged between 45 and 54 years old, and who have an incomplete elementary education [34].

Entrepreneurship in Portugal is essentially based on an ecosystem close to that advocated by researchers [38], in which there is a set of interconnected entrepreneurs who control entrepreneurial organizations (firms) and collaborate with the public (universities and the public sector) and private institutions (banks, organizations). Several studies have identified the main barriers that entrepreneurs face in Portugal, which are: (1) lack of access to networks and business contacts [39], (2) psychological and cultural limitations in accessing the entrepreneurial activity [40], (3) low level of self-efficacy and corporate ambition [41], (4) lack of capital to finance start-up and business growth [42], (5) lack of transparency and predictability of the legislative and regulatory environment [43], (6) reduced number of entrepreneurship education programs [44], (7) lack of high growth companies [45], (8) lack of programs of "procurement" by the public administration aimed at start-ups [46], (9) residual number of success cases within the entrepreneurship ecosystem [47], and (10) lack of involvement of large companies in the entrepreneurship ecosystem [48].

Regarding entrepreneurship education, there is an academic need for greater transversality of educational programs and more innovative learning methodologies [44]. In this sense, public authorities, especially those related to employment and education, should actively promote entrepreneurial education to increase the entrepreneurial spirit, confidence, initiative, and self-esteem of the future generations of successful entrepreneurs [39]. These possible success cases would make entrepreneurship education programs more interesting, dynamic, and able to increase society's wealth and well-being. They could also increase large companies' involvement if the mentioned barriers are lowered, reducing the efficiency problems related to the implementation of such programs [49].

\section{Methods}

\subsection{Data Collection Tools}

In order to collect data, a survey questionnaire was constructed (please see the Appendix A) and distributed both online and in-person. This survey used McClelland's (1972) [24] perspective with a sample of university students. Data were collected through a standard closed questionnaire with 55 items scored using a Likert-type scale. Scores were computed based on each respondent's level of EBCs with a specific definition, as in Table 2.

Questions 11, 22, 33, 44, and 55 correspond to the correction factor, used to prevent even unconscious answers from being overly favourable. The correction factor is used only if the sum of the score of the questions of each characteristic is equal to or higher than 20 points. In this case, all EBCs should be corrected by subtracting the corresponding points [50]. 
Table 2. Computation of entrepreneurial behavioural characteristics (EBCs).

\begin{tabular}{cc}
\hline Entrepreneurial Behavior Characteristics & Score's Computation \\
\hline Search for opportunity & $\mathrm{Q} 1+\mathrm{Q} 12+\mathrm{Q} 23-\mathrm{Q} 34+\mathrm{Q} 45+6$ \\
Persistence & $\mathrm{Q} 2+\mathrm{Q} 13+\mathrm{Q} 24-\mathrm{Q} 35+\mathrm{Q} 46+6$ \\
Commitment & $\mathrm{Q} 3+\mathrm{Q} 14+\mathrm{Q} 25+\mathrm{Q} 36-\mathrm{Q} 47+6$ \\
Exigence of Quality & $\mathrm{Q} 4+\mathrm{Q} 15+\mathrm{Q} 26+\mathrm{Q} 37+\mathrm{Q} 48+0$ \\
Taking calculated risks & $\mathrm{Q} 5+\mathrm{Q} 16+\mathrm{Q} 27-\mathrm{Q} 38+\mathrm{Q} 49+6$ \\
Goals' definition & $\mathrm{Q} 6-\mathrm{Q} 17+\mathrm{Q} 28+\mathrm{Q} 39+\mathrm{Q} 50+6$ \\
Search for data & $\mathrm{Q} 7+\mathrm{Q} 18-\mathrm{Q} 29+\mathrm{Q} 40+\mathrm{Q} 51+6$ \\
Planning & $\mathrm{Q} 8+\mathrm{Q} 19+\mathrm{Q} 30-\mathrm{Q} 41+\mathrm{Q} 52+6$ \\
Persuasion & $\mathrm{Q} 9-\mathrm{Q} 20+\mathrm{Q} 31+\mathrm{Q} 42+\mathrm{Q} 53+6$ \\
Independence & $\mathrm{Q} 10-\mathrm{Q} 21+\mathrm{Q} 32+\mathrm{Q} 43+\mathrm{Q} 54+6$ \\
Correction Factor & $\mathrm{Q} 11-\mathrm{Q} 22-\mathrm{Q} 33-\mathrm{Q} 44+\mathrm{Q} 55+18$ \\
\hline
\end{tabular}

There are several negative questions, in which the score must be subtracted from the final result of the sum of the questions related to that characteristic, and six points should be added at the end of the sum (see the computation for "search for opportunity" or for "persistence," for examples). The maximum score for each characteristic is 25 points; when the total is equal to or greater than 15 points, it is claimed that the individual has developed that characteristic. To be considered a successful entrepreneur, one must have developed all 10 characteristics [50].

McClelland (1972) [24] pointed out that, as the questions of the instrument are subjective, they reflect the moment the respondent is in. The data analysis was based on exploratory factor analysis, using the main component method and Varimax rotation with SPSS 26 software, and confirmatory factor analysis, using structural equation modelling (SEM) with Amos 26 software.

\subsection{Participants and Procedures}

The respondents were undergraduate students from public universities in Brazil and Portugal. In Brazil, the university selected (the Federal University of the Southern Frontier) is located in the south of the country, and offers nine undergraduate degree programs in different areas. In total, the surveyed programs accounted for 1653 students in 2019. The students surveyed were from bachelor's degree programs in agronomy, environmental and sanitary engineering, and architecture and urbanism.

In Portugal, students from two universities in the north of the country (the University of Minho and the University of Trás-os-Montes and Alto Douro) were surveyed, with a total of 153 students and an average age of 21 years old (Appendix A). The students surveyed at the University of Minho numbered 72, representing the economics bachelor's degree, the master's in economics, and the master's in social economy. The students surveyed at the University of Trás-os-Monte and Alto Douro numbered 81, and represented the economics bachelor's degree and management bachelor's degree.

The final sample comprised of 329 students-176 Brazilians and 153 Portuguese students. Table 3 summarizes the sample information.

Table 3. Identification of population and sample.

\begin{tabular}{ccccc}
\hline Sample & Nationality & \multicolumn{2}{c}{ Gender } & Age (Mean) \\
\hline 176 & Brazilian & 80 women & 96 men & 23 years \\
153 & Portuguese & 92 women & 61 men & 21 years \\
329 & Brazilian and Portuguese & 172 women & 157 men & 22 years \\
\hline
\end{tabular}

In addition, as well as the distributed form and the descriptive statistics in relation to the total sample and each sub-sample, there were also statistical differences between the answers given to the 55 questions by Brazilian and Portuguese students. 
Considering the entire sample, the highest means were in Questions 14 (4.4043) and 6 (4.3556), the first being part of the issues related to commitment characteristics and the second to setting goals. The lowest means were from Questions 17 (1.4468) and 29 (2.4863), related to the characteristics information search and goal setting, respectively.

In the group of Brazilian students, the highest mean was from Question 6 (4.4886) related to the commitment characteristic, and the lowest mean was from Question 17 (1.3352), related to the goal setting characteristic. These were in agreement with those of the total sample. These results differed for the Portuguese students. The highest mean in this group was from Question 5 (4.6601) concerning the calculated risk-taking characteristic, and the lowest was from Question 29 (2.5098), related to the information-seeking characteristic. It is also clear that the standard deviation of the responses of the sample of Portuguese students was lower than that of the Brazilian students.

\subsection{Confirmatory Factorial Analysis (CFA)}

To perform the CFA, we tested a model that, first, included all dimensions; if the dimensions got a loading factor lower than 0.5 , they were removed for statistical consistency in terms of variable adjustment [51]. The analysis of the research model that was proposed resorted to confirmatory factor analysis (CFA), using a structural equation model (SEM) and SPSS/AMOS 26 software [52]. The mediation model was tested (for validity and reliability of the measures) in accordance with the literature, and several research hypotheses were tested to determine the meaning of loadings and coefficients of each path [53,54].

Table 4 shows the model's convergence statistics, which present sufficient validity and reliability. The sample size met the criteria for the structural equation analysis, which suggests that there should be a minimum of five interviewees for each variable of the model [55,56]. Hair et al. (2010) [55] corroborated this threshold, but proposed more complex models with less indicators for construction and larger samples. According to the sources mentioned earlier, it is fair to say that the sample collected was sufficiently representative to be used in a structural equation model. The structural equation model that was presented enabled a multivariate analysis, which allowed for the testing of more complex models than the traditional linear regression model [57].

Table 4. Quality index of the adjustment of the models tested.

\begin{tabular}{cccc}
\hline Adjustment Index & $\begin{array}{c}\text { Model Tested } \\
\text { PT + BR }\end{array}$ & $\begin{array}{c}\text { Model Tested } \\
\text { PT }\end{array}$ & $\begin{array}{c}\text { Model Tested } \\
\text { BR }\end{array}$ \\
\hline$\chi^{2}$ Satorra Bentler & 117.849 & 51.640 & 91.659 \\
$d f$ & 35 & 35 & 35 \\
$p$-value & $p<.001$ & $p<0.001$ & $p<0.001$ \\
$\frac{\chi}{d f}$ Satorra Bentler & 3.367 & 1.475 & 2.619 \\
RMSEA & 0.065 & 0.056 & 0.096 \\
SRMR & 0.0495 & 0.0490 & 0.0595 \\
NFI & 0.895 & 0.893 & 0.805 \\
GFI & 0.839 & 0.899 & 0.809 \\
AGFI & 0.785 & 0.895 & 0.885 \\
CFI & 0.905 & 0.914 & 0.847 \\
\hline
\end{tabular}

\section{Results}

\subsection{Total Sample}

In Table 5, a summary of the hypotheses that were tested is presented, considering the best research model as well as the results that were obtained. 
Table 5. Research hypotheses and statistical results—Portuguese (PT) + Brazilian (BR) model.

\begin{tabular}{ccccccc}
\hline Hypotheses & Relation & $\begin{array}{c}\text { Regression } \\
\text { Coefficient }\end{array}$ & $\begin{array}{c}\text { Standard } \\
\text { Error }\end{array}$ & T & $p$-Value & Result \\
\hline H1 & SOO $\rightarrow$ EA & 0.341 & 0.290 & 4.420 & $<0.001$ & Supported \\
H2 & TCR $\rightarrow$ EA & 0.140 & 0.293 & 2.172 & $<0.05$ & Supported \\
H3 & EOQ $\rightarrow$ EA & 0.389 & 0.221 & 4.790 & $<0.001$ & Supported \\
H4 & PER $\rightarrow$ EA & 0.673 & 0.259 & 6.074 & $<0.001$ & Supported \\
H5 & COM $\rightarrow$ EA & 0.434 & 0.210 & 5.086 & $<0.001$ & Supported \\
H6 & SFD $\rightarrow$ EA & 0.608 & 0.294 & 5.883 & $<0.001$ & Supported \\
H7 & GOD $\rightarrow$ EA & 0.736 & 0.350 & 6.216 & $<0.001$ & Supported \\
H8 & PLA $\rightarrow$ EA & 0.499 & 0.255 & 5.435 & $<0.001$ & Supported \\
H9 & PSU $\rightarrow$ EA & 0.552 & 0.224 & 5.675 & $<0.001$ & Supported \\
H10 & IND $\rightarrow$ EA & 0.536 & 0.267 & 2.899 & $<0.001$ & Supported \\
\hline
\end{tabular}

First, all of the dimensions were statistically significant in the tested research model. The structural results point to all dimensions having a direct positive and statistically significant influence on EA, validating all research hypotheses proposed (Figure 1) [23,24,58]. We observed the following estimates: SOO $(\beta=0.341, p<0.001), \operatorname{PER}(\beta=0.673, p<0.001)$, GOD $(\beta=0.736, p<0.001)$, PLA $(\beta=0.499, p<0.001)$, PSU $(\beta=0.552, p<0.001)$, COM $(\beta=0.434, p<0.001)$, EOQ $(\beta=0.389, p<0.001)$, TCR $(\beta=0.140, p<0.05)$, SFD $(\beta=0.608$, $p<0.001)$, and IND $(\beta=0.536, p<0.001)$.

The results that were obtained also allowed for concluding that all dimensions that affected students' entrepreneurship attributes were relevant and statistically robust. It should be noted that the TCR dimension had an impact on EAs, but with a smaller statistical significance.

We recognize that the GOD, PER, and SFD dimensions proved to be the most pertinent dimensions concerning the increase of EAs.

Our results suggest that most of the variance of the dependent variables was accounted for in our estimation. In general, most of the variables were highly correlated, strongly affecting the EAs.

\subsection{Portuguese Sample}

In Table 6, a summary of the hypotheses that were tested with the Portuguese student sample is presented. Analyzing these data, we can conclude that the regression coefficients related to our 10 hypotheses are as follows: SOO $(\beta=0.266, p<0.05)$, PER $(\beta=0.465$, $p<0.001)$, GOD $(\beta=0.552, p<0.001), \operatorname{PLA}(\beta=0.499, p<0.001), \operatorname{PSU}(\beta=0.434, p<0.001)$, $\operatorname{COM}(\beta=0.453, p<0.001)$, EOQ $(\beta=0.319, p<0.001)$, TCR $(\beta=0.052, p>0.05)$, SFD $(\beta=0.715, p<0.001)$, and IND $(\beta=0.347, p<0.001)$.

Table 6. Research hypotheses and statistical results-PT model.

\begin{tabular}{ccccccc}
\hline Hypotheses & Relation & Regression Coefficient & Standard Error & T & $p$-Value & Result \\
\hline H1 & SOO $\rightarrow$ EA & 0.266 & 0.165 & 2.365 & $<0.05$ & Supported \\
H2 & TCR $\rightarrow$ EA & 0.052 & 0.462 & 0.556 & $>0.05$ & Not Supported \\
H3 & EOQ $\rightarrow$ EA & 0.319 & 0.169 & 2.663 & $<0.05$ & Supported \\
H4 & PER $\rightarrow$ EA & 0.465 & 0.145 & 3.219 & $<0.001$ & Supported \\
H5 & COM $\rightarrow$ EA & 0.453 & 0.174 & 3.187 & $<0.001$ & Supported \\
H6 & SFD $\rightarrow$ EA & 0.715 & 0.195 & 3.659 & $<0.001$ & Supported \\
H7 & GOD $\rightarrow$ EA & 0.552 & 0.199 & 3.431 & $<0.001$ & Supported \\
H8 & PLA $\rightarrow$ EA & 0.650 & 0.175 & 3.589 & $<0.001$ & Supported \\
H9 & PSU $\rightarrow$ EA & 0.434 & 0.163 & 3.129 & $<0.001$ & Supported \\
H10 & IND $\rightarrow$ EA & 0.347 & 0.105 & 2.009 & $<0.001$ & Supported \\
\hline
\end{tabular}


Furthermore, all of the dimensions were statistically significant in the tested research model, except for the TCR dimension. The structural results point to all dimensions having a direct positive and statistically significant influence on EAs, validating all research hypotheses proposed, except $\mathrm{H} 2$.

Several studies by Portuguese authors found results close to those presented here [59-61].

\subsection{Brazilian Sample}

Table 7 shows a summary of the hypotheses that were tested with the Brazilian student sample. Analyzing these data, we conclude that the regression coefficients related to our 10 hypotheses tested with the Brazilian sub-sample are as follows: SOO $(\beta=0.521$, $p<0.001)$, PER $(\beta=0.538, p<0.001)$, GOD $(\beta=0.721, p<0.001), \operatorname{PLA}(\beta=0.516, p<0.001)$, PSU $(\beta=0.630, p<0.001), \operatorname{COM}(\beta=0.468, p<0.001)$, EOQ $(\beta=0.423, p<0.001)$, TCR $(\beta=0.405, p<0.001), \operatorname{SFD}(\beta=0.659, p<0.001)$, and IND $(\beta=0.147, p<0.001)$.

Table 7. Research hypotheses and statistical results-BR model.

\begin{tabular}{ccccccc}
\hline Hypotheses & Relation & $\begin{array}{c}\text { Regression } \\
\text { Coefficient }\end{array}$ & $\begin{array}{c}\text { Standard } \\
\text { Error }\end{array}$ & T & $p$-Value & Result \\
\hline H1 & SOO $\rightarrow$ EA & 0.521 & 0.181 & 4.023 & $<0.001$ & Supported \\
H2 & TCR $\rightarrow$ EA & 0.405 & 0.167 & 3.568 & $<0.001$ & Supported \\
H3 & EOQ $\rightarrow$ EA & 0.423 & 0.220 & 3.651 & $<0.001$ & Supported \\
H4 & PER $\rightarrow$ EA & 0.538 & 0.146 & 4.076 & $<0.001$ & Supported \\
H5 & COM $\rightarrow$ EA & 0.468 & 0.184 & 3.838 & $<0.001$ & Supported \\
H6 & SFD $\rightarrow$ EA & 0.659 & 0.215 & 4.372 & $<0.001$ & Supported \\
H7 & GOD $\rightarrow$ EA & 0.721 & 0.227 & 4.480 & $<0.001$ & Supported \\
H8 & PLA $\rightarrow$ EA & 0.516 & 0.223 & 4.007 & $<0.001$ & Supported \\
H9 & PSU $\rightarrow$ EA & 0.630 & 0.173 & 4.313 & $<0.001$ & Supported \\
H10 & IND $\rightarrow$ EA & 0.147 & 0.005 & 1.009 & $<0.001$ & Supported \\
\hline
\end{tabular}

Contrary to the Portuguese students, in the Brazilian sample, all the dimensions were statistically significant in the research model tested. The structural results point to all dimensions having a direct positive and statistically significant influence on EA, validating all research hypotheses proposed.

These results were also found by Ching and Kitahara (2017) [4] in a study conducted with Brazilian academics.

\subsection{Discussion}

This work is a pioneering work in the analysis of entrepreneurship of a university nature, comparing the reality in Brazilian and Portuguese universities.

Overall, our results made it possible to recognize the validation of the entrepreneurial attributes that McClelland pointed out more than fifty years ago [40]. This perception is relevant, because, in addition to bringing the McClelland model to the current questionnaires in the area of entrepreneurship, it also allows for exploring the evidence obtained through a pertinent comparison between different realities, namely between countries.

Our results generally validated the totality of the attributes identified by McClelland. However, in a very stimulating way, they also allowed for showing that there are differences that deserve to be explored in future works. For example, the sample of Portuguese university students is more risk-averse than the sample of Brazilian university students. It is intended that future investigations in the area should seek reasons for this discrepancy, seeking to test the surrounding socio-economic realities as well as institutional reasons for this difference in results. In addition, the Brazilian sample greatly valued the dimensions GOD (goals) and SFD (search for data).

\section{Conclusions, Implications, and Further Challenges}

Entrepreneurship has become one of the most frequently studied academic fields in the last two decades. In areas as diverse as management, engineering, and social work, 
entrepreneurship has emerged as both a curricular unit and as a subject area for disciplinary research at most universities.

If this dispersion is a fact, then the molds in which entrepreneurial characteristics have been developed have also differed. To this end, the different realities that students and teachers live in their contexts of teaching and learning can help to explain it.

This work tested the presence of the entrepreneurial behavioural characteristics model developed by McClelland in Portuguese and Brazilian universities. It achieved promising results. These results validated the McClelland model in the observed samples, as well as the presence of a single factor identified by structural equation analysis.

Thus, there are two main implications. The first implication concerns the validation of the model. Although the McClelland model is 50 years old, validating the presence of entrepreneurial behavioural characteristics in the samples identified here reveals not only how the McClelland model provides a stimulating methodological framework for discussion in the academic context, but also for the design of entrepreneurship-promoting policies among academic communities and other groups of entrepreneurs. The second implication, concerning the presence of a factor, shows how the studied samples, despite the differences of nationality, curriculum matrices, and surrounding contexts, reveal a certain homogeneity in terms of answers to the 55 items addressed in the distributed questionnaire. This implication reveals that there is a latent dimension that unites entrepreneurs, thus, offering additional research motivations and extending the study of entrepreneurial behavior to areas such as psychology, sociology, and anthropology.

Regarding subsequent challenges, three are emerging. First, we will extend this analytical effort to other actors of the observation academies, namely teachers and administrators. Second, we intend to include other academic institutions (including other lusophone countries) for a more robust McClelland model validation test. Finally, through a longitudinal analysis, we intend to examine whether respondents maintain the response structure after the completion of the study cycle, as well as after a period of professional experience.

Author Contributions: Conceptualization, P.J.R.M.; Data curation, D.R.S.L. and R.S.; Formal analysis, D.R.S.L. and R.S.; Funding acquisition, P.J.R.M. and R.S.; Investigation, D.R.S.L., P.J.R.M. and R.S.; Methodology, R.S.; Project administration, P.J.R.M.; Resources, D.R.S.L.; Software, R.S.; Validation, P.J.R.M.; Writing—original draft, D.R.S.L., P.J.R.M. and R.S.; Writing—review \& editing, D.R.S.L., P.J.R.M. and R.S. All authors have read and agreed to the published version of the manuscript.

Funding: This research was funded by Fundação para a Ciência e a Tecnologia, UIDB/04011/2020. The work of the author Rui Silva is supported by national funds, through the FCT-Portuguese Foundation for Science and Technology under the project UIDB/04011/2020. The work of the author Paulo Mourão is financed by NIPE (Center for Research in Economics and Management), University of Minho, Braga, Portugal.

Acknowledgments: The author Rui Silva gratefully acknowledge University of Trás-os-Montes and Alto Douro and CETRAD (Center for Transdisciplinary Development Studies). The author Paulo Mourão acknowledges the following: "This paper is financed by National Funds of the FCT—Portuguese Foundation for Science and Technology within the project «UIDB/03182/2020»".

Institutional Review Board Statement: Not applicable.

Informed Consent Statement: Informed consent was obtained from all subjects involved in the study. Data Availability Statement: Not applicable.

Conflicts of Interest: The authors declare no conflict of interest.

Appendix A McClelland Questionnaire for the Entrepreneur Profile Self-Assessment of Entrepreneurial Behavior Characteristics (EBCs)

This questionnaire consists of 55 brief statements. Read each statement carefully and decide which one best describes you (consider who you are today and not how you would like to be). Be honest with yourself. Some statements may be similar, but none are exactly the same. Please designate a numerical classification for all statements. 
Select the number that corresponds to the statement that best describes you:

$1=$ Never $/ 2=$ Rarely $/ 3=$ Sometimes $/ 4=$ Usually $/ 5=$ Always

\begin{tabular}{|c|c|}
\hline & Question \\
\hline 1 & I strive to accomplish the things that must be done. \\
\hline 2 & When I come across a difficult problem, it takes me a long time to find the solution. \\
\hline 3 & I finish my work on time. \\
\hline 4 & I hate myself when things are not done properly. \\
\hline 5 & I prefer situations where I can control to the maximum the final result. \\
\hline 6 & I like to think about the future. \\
\hline 7 & $\begin{array}{l}\text { When I begin a new task or project, I gather as much information as possible before } \\
\text { proceeding. }\end{array}$ \\
\hline 8 & I plan a big project by dividing it into simpler tasks. \\
\hline 9 & I can get others to support my recommendations. \\
\hline 10 & I have confidence that I can be successful in any activity that I propose to perform. \\
\hline 11 & No matter who I speak with, I always listen closely. \\
\hline 12 & I do the things that must be done without others having to ask me. \\
\hline 13 & I insist several times to get other people to do what I want. \\
\hline 14 & I am faithful to the promises I make. \\
\hline 15 & My work income is better than that of other people I work with. \\
\hline 16 & $\begin{array}{l}\text { I get involved with something new only after I have done my best to ensure its } \\
\text { success. }\end{array}$ \\
\hline 17 & I find it a waste of time to worry about what I will do with my life. \\
\hline 18 & I seek advice from people who are experts in the field in which I am working. \\
\hline 19 & $\begin{array}{l}\text { I carefully consider the advantages and disadvantages of different alternatives } \\
\text { before I undertake a task. }\end{array}$ \\
\hline 20 & I do not waste much time thinking about how I can influence other people. \\
\hline 21 & I change the way people think if others strongly disagree with my views. \\
\hline 22 & I hate myself when I cannot get what I want. \\
\hline 23 & I like challenges and new opportunities. \\
\hline 24 & When something stands between what I'm trying to do, I persist in my task. \\
\hline 25 & If necessary, I do not mind doing the work of others to meet a deadline. \\
\hline 26 & I hate myself when I waste time. \\
\hline 27 & I consider my chances of success or failure before I start acting. \\
\hline 28 & $\begin{array}{l}\text { The more specific my expectations are in relation to what I want to achieve in life, } \\
\text { the greater my chances of success. }\end{array}$ \\
\hline 29 & I make decisions without wasting time looking for information. \\
\hline 30 & $\begin{array}{l}\text { I try to take into account all the problems that may present themselves and } \\
\text { anticipate what I would do if they happen. }\end{array}$ \\
\hline 31 & I count on influential people to reach my goals. \\
\hline
\end{tabular}




\begin{tabular}{|c|c|}
\hline & Question \\
\hline 32 & $\begin{array}{l}\text { When I am performing something difficult and challenging, I have confidence in } \\
\text { your success. }\end{array}$ \\
\hline 33 & I've had failures in the past. \\
\hline 34 & I prefer to perform tasks that I master perfectly and in which I feel safe. \\
\hline 35 & When I encounter serious difficulties, I quickly move on to other activities. \\
\hline 36 & $\begin{array}{l}\text { When I am doing a job for someone else, I make a special effort to be satisfied with } \\
\text { the work. }\end{array}$ \\
\hline 37 & $\begin{array}{l}\text { I'm never really satisfied with the way things are done; I always think there is a } \\
\text { better way to do them. }\end{array}$ \\
\hline 38 & I perform risky tasks. \\
\hline 39 & I count on a clear plan of life. \\
\hline 40 & $\begin{array}{l}\text { When I do a project for someone, I ask many questions to make sure I understand } \\
\text { what they want. }\end{array}$ \\
\hline 41 & I face problems as they arise instead of wasting time anticipating them.. \\
\hline 42 & To reach my goals, I look for solutions that benefit everyone involved in a problem. \\
\hline 43 & The work I do is excellent. \\
\hline 44 & On some occasions, I have taken advantage of other people. \\
\hline 45 & I venture to do new and different things. \\
\hline 46 & $\begin{array}{l}\text { I have different ways of overcoming obstacles that prevent me from achieving my } \\
\text { goals. }\end{array}$ \\
\hline 47 & $\begin{array}{l}\text { My family and personal life are more important to me than the dates for deliveries } \\
\text { of self-determined works. }\end{array}$ \\
\hline 48 & I find the fastest way to finish work, both at home and at work. \\
\hline 49 & I do things that people consider risky. \\
\hline 50 & I care as much about meeting my weekly goals as my annual goals. \\
\hline 51 & $\begin{array}{l}\text { I count on various sources of information when seeking help in the execution of } \\
\text { tasks and projects. }\end{array}$ \\
\hline 52 & If one method for dealing with a problem does not work, I turn to another. \\
\hline 53 & I can get people with firm beliefs and opinions to change their way of thinking. \\
\hline 54 & I remain firm in my decisions, even when other people are strongly opposed. \\
\hline 55 & When I do not know something, I do not hesitate to admit it. \\
\hline
\end{tabular}

\section{References}

1. Filion, L.J. Diferenças entre sistemas gerenciais de empreendedores e operadores de pequenos negócios. Rev. Adm. Empresas 1999, 39, 6-20. [CrossRef]

2. Boava, D.L.T. Estudo Sobre a Dimensão Ontológica do Empreendedorismo. Londrina. Master's Thesis, Universidade Estadual de Londrina, Lundrina, Brazil, 2006. Available online: http:/ /livros01.livrosgratis.com.br/cp000857.pdf (accessed on 30 September 2020).

3. Schumpeter, J.A. Economic Theory and Entrepremeurial History-Change and the Entrepreur, Postulates and Parttners for Entrepremeurial History; Harvard University Press: Cambrigde, MA, USA, 1949.

4. Ching, H.Y.; Kitahara, J.R. Avaliação da Propensão a Empreender: Uma Proposta de Mensuração Desse Constructo. Rev. Empreendedorismo Gestão Pequenas Empresas 2017, 6, 291-310. [CrossRef]

5. Al-Jubari, I.; Hassan, A.; Liñán, F. Entrepreneurial intention among University students in Malaysia: Integrating self-determination theory and the theory of planned behavior. Int. Entrep. Manag. J. 2019, 15, 1323-1342. [CrossRef]

6. Fragoso, R.; Rocha-Junior, W.; Xavier, A. Determinant factors of entrepreneurial intention among university students in Brazil and Portugal. J. Small Bus. Entrep. 2020, 32, 33-57. [CrossRef]

7. Dvorský, J.; Mikelová, L.; Petráková, Z.; Rózsa, Z. Impact of social attributes on the propensity for entrepreneurship among university students. J. Int. Stud. 2019, 12, 253-268. [CrossRef] 
8. Hahn, D.; Minola, T.; Bosio, G.; Cassia, L. The impact of entrepreneurship education on university students' entrepreneurial skills: A family embeddedness perspective. Small Bus. Econ. 2019. [CrossRef]

9. De Bizarria, F.P.A.; Barbosa, F.L.S.; Sousa, A.M.R. Autodeterminação e Empreendedorismo com Suporte em Motivações: Análise empírica com universitários do curso de administração. Rev. Eletrôn. Ciênc. Adm. 2019, 18, 281-304. [CrossRef]

10. Martínez-Campillo, A.; del Sierra-Fernández, M.P.; Fernández-Santos, Y. Service-learning for sustainability entrepreneurship in rural areas: What is its global impact on business university students? Sustainability 2019, 11, 5296. [CrossRef]

11. Aykan, E.; Karakuş, G.; Karakoç, H. The effect of university students' individual innovation and lifelong learning trends on entrepreneurship orientation. Sustainability 2019, 11, 6201. [CrossRef]

12. Hendieh, J.; Aoun, D.; Osta, A. Students' attitudes toward entrepreneurship at the Arab Open University-Lebanon. J. Entrep. Educ. 2019, 22, 1-13.

13. Ali, I.; Ali, M.; Badghish, S. Symmetric and asymmetric modeling of entrepreneurial ecosystem in developing entrepreneurial intentions among female university students in Saudi Arabia. Int. J. Gend. Entrep. 2019, 11, 435-458. [CrossRef]

14. Bazan, C.; Shaikh, A.; Frederick, S.; Amjad, A.; Yap, S.; Finn, C.; Rayner, J. Effect of memorial university's environment \& support system in shaping entrepreneurial intention of students. J. Entrep. Educ. 2019, 22, 1-35.

15. Belas, J.; Gavurova, B.; Korony, S.; Cepel, M. Attitude of University Students toward entrepreneurship environment and toward entrepreneurship propensity in Czech Republic and Slovak Republic-International Comparison. Econ. Res. Ekon. Istraz. 2019, 32, 2500-2514. [CrossRef]

16. Fontela, E.; Guzmán, J.; Pérez, M.; Santos, F. The art of entrepreneurial foresight. Foresight 2006, 8, 3-13. [CrossRef]

17. Guerra, M.J.; Grazziotin, Z.J. Educação empreendedora nas universidades brasileiras. In Educação Empreendedora: Conceitos, Modelos E Práticas; Lopes, R.M.A., Ed.; Elsevier: Rio de Janeiro, Brazil, 2010.

18. Hisrich, R.D.; Peters, M.P. Empreendedorismo, 5th ed.; Bookmann: Porto Alegre-RS, Brazil, 2004.

19. Filion, L.J. Empreendedorismo e gerenciamento: Processos distintos, porém complementares. RAE Light 2000, 7, 2-7. [CrossRef]

20. Dolabela, F. Oficina Do Empreendedor; Sextante: Rio de Janeiro, Brazil, 2008.

21. Drucker, P.F. Inovação E Espírito Empreendedor: Prática E Princípios; Cengage Learning: São Paulo, Brazil, 2016.

22. Pradhan, R.K.; Nath, P. Perception of entrepreneurial orientation and emotional intelligence: A study on India's future technomanagers. Glob. Bus. Rev. 2012, 13, 89-108. [CrossRef]

23. McClelland, D.C. Toward a Theory of Motive Acquisition. Am. Psychol. 1965, 20, 321-333. [CrossRef]

24. McClelland, D.C.; Burnham, D.H. A Sociedade Competitiva: Realização E Progresso Social; Expressão e Cultura: Rio de Janeiro, Brazil, 1972.

25. McClelland, D.C. Motivational Patterns in Southeast Asia with Special Reference to the Chinese Case. J. Soc. Issues 1963, 19, 6-19. [CrossRef]

26. McClenlland, D.C. The Achieving Society; Van Nostrand: Princeton, NJ, USA, 1961.

27. Boava, D.L.T.; Macedo, F.M.F. Estudo Sobre a Essência do Empreendedorismo; Anais do Encontro da Associação Nacional de Pós-Graduação e Pesquisa em Administração: Salvador, Brasil, 2006; Volume 30.

28. Management Systems International. Entrepreneurship Training and the Strengthening of Entrepreneurial Performance; Management Systems International: Washington, DC, USA, 1990.

29. Brancher, I.B.; Oliveira, E.M.; Roncon, A. Comportamento empreendedor: Estudo bibliométrico da produção nacional e a influência de referencial teórico internacional. Rev. Eletrôn. Neg. Int. (Internext) 2012, 7, 166-193.

30. Raupp, F.M.; Beuren, I.M. Perfil do suporte oferecido pelas incubadoras brasileiras às empresas incubadas. REAd Rev. Eletrôn. Adm. 2011, 17, 330-359. [CrossRef]

31. Daud, S.N.; Abdullah, M.; Abu Hassan, N. Exploratory Factor Analysis of Entrepreneurship Traits Among Engineering Students. Int. J. Entrep. Manag. Pract. 2019, 39-50. [CrossRef]

32. Snedecor, G.W.; Cochran, W.G. Statistical Methods, 8th ed.; Iowa State University Press: Iowa City, IA, USA, 1989.

33. Ajzen, I. The theory of planned behavior. Organ. Behav. Hum. Decis. Process. 1991, 50, 179-211. [CrossRef]

34. Global Entrepreneurship Research Association. Empreendedorismo No Brasil-2019. 2020. Available online: https://ibqp.org. br/wp-content/uploads/2021/02/Empreendedorismo-no-Brasil-GEM-2019.pdf (accessed on 10 October 2020).

35. Kurniawan, M.E.H.; Yudoko, G.; Basri, M.H.; Umbara, A.N. Do entrepreneurship students have an intention to become an entrepreneur? J. Entrep. Educ. 2019, 22, 1-14.

36. Sá, C.; Holt, C. Profiles of entrepreneurship students: Implications for policy and practice. Educ. Train. 2019, 61, 122-135. [CrossRef]

37. Felix, C.; Aparicio, S.; Urbano, D. Entrepreneurial leadership across countries: The role of informal institutions. In Entrepreneurship and Family Business Vitality. Studies on Entrepreneurship, Structural Change and Industrial Dynamics; Saiz-Álvarez, P.-R.J., Leitão, J., Eds.; Springer: Cham, Switzerland, 2020; pp. 67-83.

38. Mason, C.; Brown, R. Creating good public policy to support high-growth firms. Small Bus. Econ. 2013, 40, 211-225. [CrossRef]

39. Jain, R.; Ali, S.W. A review of facilitators, barriers and gateways to entrepreneurship: Directions for future research. South Asian J. Manag. 2013, 20, 122.

40. Fuerlinger, G.; Fandl, U.; Funke, T. The role of the state in the entrepreneurship ecosystem: Insights from Germany. Triple Helix 2015, 2, 1-26. [CrossRef]

41. Shane, S.A. A General Theory of Entrepreneurship: The Individual-Opportunity Nexus; Edward Elgar Publishing: Cheltenham, UK, 2003. 
42. Liu, M.M. Angels without Borders: Trends and Policies Shaping Angel Investment Worldwide; World Scientific: Singapore, 2015.

43. Auerswald, P.E. Enabling entrepreneurial ecosystems: Insights from ecology to inform effective entrepreneurship policy. In Kauffman Foundation Research Series on City, Metro, and Regional Entrepreneurship; Ewing Marion Kauffman Foundation: Kansas City, MO, USA, 2015.

44. Bourgeois, A.; Balcon, M.-P. Entrepreneurship Education at School in Europe; Eurydice Report; Education, Audiovisual and Culture Executive Agency, European Commission: Brussels, Belgium, 2016.

45. Henrekson, M.; Johansson, D. Gazelles as job creators: A survey and interpretation of the evidence. Small Bus. Econ. 2010, 35, 227-244. [CrossRef]

46. Li, Y.; Georghiou, L. Signaling and accrediting new technology: Use of procurement for innovation in China. Sci. Public Policy 2016, 43, 338-351. [CrossRef]

47. Napier, G.; Hansen, C. Ecosystems for Young Scalable Firms; FORA Group: Ankara, Turkey, 2011.

48. Hockerts, K.; Wüstenhagen, R. Greening Goliaths versus emerging Davids-Theorizing about the role of incumbents and new entrants in sustainable entrepreneurship. J. Bus. Venturing 2010, 25, 481-492. [CrossRef]

49. Banha, F.M.; Almeida, M.H.; Rebelo, E.L.; Ramos, A.O. The main barriers of Portuguese entrepreneurship ecosystem: Interpretive Structural Modeling (ISM) approach. Tour. Manag. Stud. 2017, 13, 60-70. [CrossRef]

50. Mansfield, R.S.; Mcclelland, D.C.; Spencer, J.L.M.; Santiago, J. The Identification and Assessment of Competencies and Other Personal Characteristics of Entrepreneurs in Developing Countries; McBer and Compay: Boston, MA, USA, 1987.

51. Brown, T.A. Confirmatory Factor Analysis for Applied Research; Guilford: New York, NY, USA, 2006.

52. Ringle, C.M.; Wende, S.; Becker, J.-M. SmartPLS 3. Boenningstedt SmartPLS GmbH. 2015. Available online: http:/ / www.smartpls. com (accessed on 12 December 2020).

53. Krueger, N.; Carsrud, A. Entrepreneurial intentions: Applying the theory of planned behaviour. Entrep. Reg. Dev. 1993, 5, 315-330. [CrossRef]

54. Hair, J.F., Jr.; Sarstedt, M.; Hopkins, L.; Kuppelwieser, G. Partial least squares structural equation modeling (PLS-SEM) An emerging tool in business research. Eur. Bus. Rev. 2014, 26, 106-121. [CrossRef]

55. Hair, J.F.; Black, W.C.; Babin, B.J.; Anderson, R.E.; Tatham, R.L. Multivariate Data Analysis; Pearson: London, UK, 2010.

56. Hoelter, J.W. The analysis of covariance structures: Goodness-of-fit indices. Sociol. Methods Res. 1983, 11, 325-344. [CrossRef]

57. Bagozzi, R.P.; Yi, Y. Specification, evaluation, and interpretation of structural equation models. J. Acad. Mark. Sci. 2012, 40, 8-34. [CrossRef]

58. Mcclelland, D.C. The Knowledge-Testing- Educational Complex Strikes Back. Am. Psychol. 1994, 49, 66-69. [CrossRef]

59. Ribeiro, M.I.; Fernandes, A.; Diniz, F. Propensão ao empreendedorismo em alunos do ensino superior: O caso de uma instituição pública do nordeste português. Rev. Empreendedorismo Gestão Micro Pequenas Empresas 2016, 1, 67-77. [CrossRef]

60. Do Rosário, A.E.M. Propensão Ao Empreendedorismo Dos Alunos Finalistas Da Universidade Do Porto; Universidade do Porto: Porto, Portugal, 2007.

61. Testas, C.P.; Moreira, F.R. O empreendedorismo no ensino superior. Gestão Desenvolv. 2014, 22, 139-163. [CrossRef] 